\title{
Study on the Current Employment Situation of Migrant Workers
}

\author{
Lili Wang \\ Institute of Economics, Heilongjiang Provincial Academy of Social Science, Harbin, China \\ Email:mlbsabc@sina.com
}

How to cite this paper: Wang, L.L. (2017) Study on the Current Employment Situation of Migrant Workers. Open Journal of Social Sciences, 5, 175-179.

http://dx.doi.org/10.4236/jss.2017.51013

Received: December 31, 2016

Accepted: January 15, 2017

Published: January 18, 2017

Copyright $\odot 2017$ by author and Scientific Research Publishing Inc. This work is licensed under the Creative Commons Attribution International License (CC BY 4.0).

http://creativecommons.org/licenses/by/4.0/

\begin{abstract}
After the Opinions of the State Council on Solving Problems of Migrant Workers is carried out, the migrant workers' situation has been improved, especially that their income has been increased greatly, the problem of wages in arrears has been abated, and the services provided by the government have been enhanced. However, some basic problems such as the migrant workers' low income and difficult life have not been changed fundamentally. Thus, in order to carry out all of the policies of solving migrant workers' problems, we should promote the institutional innovation, increase related investment, and gradually eliminate the institutional and financial obstacles of the citizenization of migrant workers; only in these ways can we solve the migrant workers' problems.
\end{abstract}

\section{Keywords}

Migrant Workers, Citizenization, Income, Education Level

\section{Introduction}

The migrant workers are a unique social group which is generated with the process of China's industrialization, urbanization and non-agriculturization of rural population. According to the estimate result of the State Council research [1], the number of migrant workers into the city in the year 2004 is 120 million, which is more than the urban workers and has grown into the second largest working group in China after the group of farmers. They have made tremendous contribution to the city and even to the whole nation's economy during these years. However, they are also the disadvantaged group as they are often treated unreasonably, and there exist many problems within this group. In March 2006, the State Council carried out the Opinions of the State Council on Solving Problems of Migrant Workers, which is the first comprehensive file on the issue of 
migrant workers in China. Then the government has carried out a series of regulations, guidelines and policies in recent years in order to solve the migrant workers' problems. Now how is the current situation of migrant workers? And what are the reasons of causing the current situation? What measures should be taken to solve the current problems? As to these issues, the Institute of Economics Heilongiiang Provincial Academy of Social Science conducted a survey of the latest situations of migrant workers in some provinces like Beijing, Shanghai, Shandong and Henan provinces. The survey gives out 1000 copies of questionnaires, collect back 825 copies, among which there are 780 effective questionnaires. According to the result of the questionnaires, we know that the education level of migrant workers is raised but still low in general, the wages of migrant workers is increased, but still lower than citizens', and there are still many young migrant workers and most migrant workers still concentrate on manufacturing and construction fields.

Comparing the China Statistical Yearbook [2] with the China Labor Statistical Yearbook [3], together with the statistic of this survey, we analyze the current situation of migrant workers, the reasons which caused the problems and give some suggested measures.

\section{The Basic Situations of Migrant Workers and Changes of the Situation}

\subsection{The Average Age of the Migrant Workers Increased Slightly, But Still with Young Adults Mainly}

In the 780 samples, the average age is 33 years old, among which $28.6 \%$ is the age between 16 and 25 years old, $12.4 \%$ is the age between 26 and 30 years old, $31 \%$ is the age between 31 and 40 years old, and $28 \%$ is the age above 40 years old. Compared to the statistics in 2015, the average age of migrant workers has been increased by 2 years old, the workers under 30 years old has been decreased by nearly $12 \%$, while workers above 40 years old has been increased by almost $13 \%$. Looking from the gender structure, the average age of female migrant workers is lower than that of the male migrant workers. The average age of female migrant workers is 30 years old, and the average age of male migrant workers is 34 year old.

\subsection{The Education Level of Migrant Workers Has Been Improved, But Still Low}

Looking from the cultural level in this research, the illiterate and semiliterate migrant workers account for $2.3 \%$, the migrant workers with primary school education account for $16.6 \%$, the migrant workers with junior high school education account for 59.6\%, the migrant workers with high school or technical secondary school education account for $19.8 \%$, while the migrant workers above college education account for $1.7 \%$ [4]. Compared to the statistics of 2010, the education level of migrant workers has been increased, but is still low in general. Details are in Table 1. 


\subsection{Migrant Workers Engaged Industries Have Been Widened, But Still Mainly in Manufacturing and Construction}

The survey shows that migrant workers employment is almost in every sector of the national economy, but concentrates in several industries [5]. In the 760 samples, the distribution of migrant workers' employment in different industries is shown in Table 2. The majority of migrant workers are still in the manufacturing and construction fields [6].

\subsection{The Wages of Migrant Workers Have Been Increased, But Still Their Economic Status Is Low}

The Survey shows that the average income of migrant workers' family is 33889 RMB in the year 2016, which increased greatly compared to that of the year 2010. But the income is still less than the income of urban resident's. The income situation of migrant workers is shown in Table 3. And from the statistics, we also conclude that migrant workers in metropolis earn more than the migrant workers in smaller cities [7].

Table 1. The changes of education levels of migrant workers.

\begin{tabular}{ccc}
\hline Time & Year 2010 & Year 2016 \\
\hline illiterate and semiliterate & $11.1 \%$ & $2.3 \%$ \\
primary school education & $15.1 \%$ & $16.6 \%$ \\
junior high school education & $58.3 \%$ & $59.6 \%$ \\
high school or technical secondary school education & $15.2 \%$ & $19.8 \%$ \\
above college education & $0.3 \%$ & $1.7 \%$ \\
\hline
\end{tabular}

Table 2. The distribution of migrant workers' employment.

\begin{tabular}{ccc}
\hline Time & Year 2010 & Year 2016 \\
\hline Manufacturing & $39.2 \%$ & $37.6 \%$ \\
Construction & $30.3 \%$ & $29.8 \%$ \\
Social Service & $5.8 \%$ & $6.1 \%$ \\
Wholesale and Retail sales & $3.9 \%$ & $4.2 \%$ \\
Lodging and Catering & $3.6 \%$ & $4.1 \%$ \\
\hline
\end{tabular}

Table 3. The migrant workers' income situation by the survey.

\begin{tabular}{cccc}
\hline Time & Year 2010 (RMB) & $\begin{array}{c}\text { Migrant workers' income } \\
\text { in Year 2016 (RMB) }\end{array}$ & $\begin{array}{c}\text { Urban residents' income } \\
\text { in Year 2016 (RMB) }\end{array}$ \\
\hline Beijing & 26891 & 58676 & 65432 \\
Shanghai & 27865 & 58761 & 68431 \\
Shandong & 16985 & 29864 & 38964 \\
Henan & 15867 & 28647 & 36785 \\
\hline
\end{tabular}




\section{The Reasons for the Current Situation of Migrant Workers}

First, the social security legislation system is not perfect. Migrant workers live between the town and countryside, the status is special. Some of the company managers do not sign contract with the migrant workers. They only have verbal contract which can not help the migrant workers when they encounter some problems.

Second, the migrant workers have limited access to social resources. Most of their time is spent on working, other time they mainly get together with their friends to talk, or play poker or surf the Internet which do not cost money or cost little money. Most of the workers don't know the free library in the city. Besides, due to the registered permanent residence system, many migrant workers can not get the city living allowance [8].

At last, the migrant workers get less education, so they don't know how to protect their rights when they encounter problems. And their legal consciousness is $\operatorname{dim}$.

\section{Conclusions and Suggested Measures}

Considering the above problems, we provide some measures. First, the government should execute strictly the national compulsory education policy and encourage the migrant workers to get high education by investing more funds.

Secondly, government should help the migrant workers to develop their local economy. In this way, migrant workers can get more opportunities in their home places. Society companies can also develop rural economy by developing rural tourism or modern agriculture and so on [9].

Third, government or media should provide more information to migrant workers so that they can get more access to the social resources. Government should build more schools for migrant workers, so migrant workers can learn more technical skills or cultural knowledge after work, which can also enrich their life after daily work.

Besides, we should also promote the innovation of institutions. The policy of point-based Hukou system has been carried out in some places like Beijing. Migrant workers can finally get registered as the permanent resident in the city, which can help the migrant workers get equal rights with the urban residents. They will also have chance to have a real home in the city. So we recommend more cities conduct this policy. It is also their citizenization process.

At last, the migrant workers should work hard and try best to learn more knowledge. And every person should care about the migrant workers and take them as a normal part of the society, just same with other people in the city. Only in this way can we truly solve the problems of migrant workers.

\section{Fund}

National Social Science Fund Project "Study On New Type Of Agricultural Operators Construction And Agricultural Modernization” (14BJY126). 


\section{References}

[1] Zheng, W. (2006) Study Selection on Development Research Center of the State Council. National Catalogue of New Books, 8, 4.

[2] China Statistical Yearbook (2004), 16-19. http://www.stats.gov.cn/tjsj/ndsj/

[3] China labor Statistical Yearbook (2010), 17-30. http://www.yearbookchina.com/navibooklist-N2011010069-1.html

[4] Zhang, D., Li, X. and Xue, J. (2015) Education Inequality between Rural and Urban Areas of the People's Republic of China, Migrants' Children Education, and Some Implications. Asian Development Review, 32, 196-224.

https://doi.org/10.1162/ADEV a 00042

[5] Li, R.J. (2005) Analysis of the Current Problems on Rural Workers' Rights. Economist, No. 9, 5-10.

[6] Ortega, M.I., Sabo, S., Gallegos, P.A., De Zapien, J.E.G., Zapien, A., Portillo Abril, G.E. and Rosales, C. (2016) Agribusiness, Corporate Social Responsibility, and Health of Agricultural Migrant Workers. Frontiers in Public Health, 4, 54. https://doi.org/10.3389/fpubh.2016.00054

[7] Li, N. and Placier, P.L. (2015) The Impact of Changes in Chinese Government Policy on Rural-Urban Migrant Children's Schooling. Asian Social Science, 11, 31-41. https://doi.org/10.5539/ass.v11n18p31

[8] Lan, P.-C. (2014) Segmented Incorporation: The Second Generation of Rural Migrants in Shanghai. The China Quarterly, 217, 243-265. https://doi.org/10.1017/S030574101300146X

[9] Zhang, H. (2005) The Analysis of Discrimination on Migrant Workers' Employment. Shanghai Economic Review, No. 10, 8-12.

\section{Scientific Research Publishing}

Submit or recommend next manuscript to SCIRP and we will provide best service for you:

Accepting pre-submission inquiries through Email, Facebook, LinkedIn, Twitter, etc. A wide selection of journals (inclusive of 9 subjects, more than 200 journals)

Providing 24-hour high-quality service

User-friendly online submission system

Fair and swift peer-review system

Efficient typesetting and proofreading procedure

Display of the result of downloads and visits, as well as the number of cited articles

Maximum dissemination of your research work

Submit your manuscript at: http://papersubmission.scirp.org/

Or contact jss@scirp.org 